Chem. Pharm. Bull.

[33( 3 )1 181-1186(1985)]

\title{
Neutral and Acidic Antitumor Polysaccharides Extracted from Cultured Fruit Bodies of Grifola frondosa
}

\author{
Naohito Ohno, ${ }^{a}$ Kazuyoshi IIno, ${ }^{a}$ Iwao Suzuki, ${ }^{a}$ Shozo OrKawa, ${ }^{b}$ \\ Kichiro Sato, ${ }^{b}$ Toshio MiYazaki, ${ }^{a}$ and Toshiro Yadomae*,a \\ Tokyo College of Pharmacy, , Horinouchi, Hachioji, Tokyo 192-03, Japan \\ and Nippon Beet Sugar Mfg. Co., Ltd., ${ }^{b}$ Kyobashi, Chuo-ku, \\ Tokyo 104, Japan
}

(Received June 20, 1984)

\begin{abstract}
Water-soluble glucan fractions extracted from the cultured fruit bodies of Grifola frondosa with hot water, and with cold and hot sodium hydroxide containing urea showed potent antitumor activity in mice (Ohno et al., Chem. Pharm. Bull., 32, 1142 (1984)). Each fraction was separated into neutral and acidic glucan fractions on a DEAE-Sephadex A-25 $\left(\mathrm{HCO}_{3}{ }^{-}\right)$column. Both neutral and acidic fractions showed potent antitumor activity against Sarcoma 180 solid tumor in ICR mice. From the results of methylation analysis and carbon-13 nuclear magnetic resonance spectroscopy, the neutral fractions contained mainly $\alpha-1,4$ and 6-branched $\beta-1,3$ linkages, and the acidic fractions contained mainly $\beta$-1,6- and 6-branched $\beta-1,3$ linkages. The branching ratio was similar in both glucans. By colorimetric analysis, each acidic fraction was found to contain about $2-5 \%$ uronic acid. These findings indicated that the cultured fruit bodies of Grifola frondosa contain neutral and acidic antitumor glucans.
\end{abstract}

Keywords - neutral polysaccharide; acidic polysaccharide; cultured fungi; Grifola frondosa; antitumor activity; $\beta-1,3$ glucan

\section{Introduction}

Grifola frondosa which belongs to the Basidiomycetes, Aphylophorales, Polypolaceae, is an edible mushroom. Hot water extracts of many kinds of mushrooms have long been used as traditional crude drugs for cancer therapy in Japan and China. It is known that the antitumor activity of polysaccharides extracted from the cultured fruit bodies of Basidiomycetes (e.g., lentinan $^{1)}$ and PS- $\mathrm{K}^{2)}$ ) was a result of activation of the immune system. Some of these polysaccharides are now used clinically for cancer therapy.

Our purpose in this series of studies is to obtain new types of antitumor glucans, and to clarify the mechanism of the glucan-mediated antitumor effect via immunomodulation. For these purposes, we used the mushroom of Grifola frondosa as a glucan source, because the mushroom is cultured and thus can be obtained easily in homogeneous lots.

In previous papers, we reported that the polysaccharide fractions extracted from the cultured fruit bodies of Grifola frondosa with hot water, and with cold and hot sodium hydroxide showed potent antitumor activity in an allogeneic system in mice. ${ }^{3)}$ We suggested that the antitumor activity was owing to a 6-branched $\beta-1,3$ glucan. Further, we obtained a polysaccharide fraction (GF-1) by the conventional copper complex method from the hot water extracts. ${ }^{4)}$ GF-1 showed potent antitumor activity in the allogeneic system in mice when it was injected intraperitoneally (i.p.), intravenously (i.v.), or intratumorally (i.t.). GF-1 also showed potent antitumor activity in syngeneic systems (Meth A-BALB/c and MM-46$\mathrm{C} 3 \mathrm{H} / \mathrm{He})$.

The previous results suggest the presence of a new type of antitumor glucan from $G$. frondosa. This paper is concerned with the neutral and acidic antitumor glucans in the 
mushroom, G. frondosa.

\section{Materials and Methods}

Mice-Male ICR mice, 6 weeks old, weighing 27-30g, were obtained from Shizuoka Agricultural Cooperative Association for Laboratory Animals, Hamamatsu.

Tumor-Sarcoma 180 tumor cells (ascites form) were kindly supplied by Dr. T. Sasaki, The National Cancer Center Research Institute, Japan, and were maintained by weekly passage in ICR mice.

Evaluation of Antitumor Activity-Antitumor activity was evaluated against the solid form of Sarcoma 180 tumor cells. Tumor cells $\left(5 \times 10^{6}\right)$ were inoculated subcutaneously into the right groin of mice. Each fraction was administered for 10 consecutive days from $24 \mathrm{~h}$ after the tumor inoculation. Five weeks after tumor inoculation, the mice were sacrificed. The inhibition was calculated as follows:

$$
\left(1-\frac{\text { average tumor weight of the treated group }}{\text { average tumor weight of the control group }}\right) \times 100(\%)
$$

Isolation of CF-1 (Hot Water Extract), CF-5 (Cold Sodium Hydroxide Extract), and CF-7 (Hot Sodium Hydroxide Extract)-_-Polysaccharide fractions were prepared from the cut fruit bodies of Grifola frondosa as described in a previous paper. ${ }^{3 /}$

Preparation of Neutral and Acidic Polysaccharide Fractions - - Each water-soluble polysaccharide fraction (CF$1,-5$, or $-7,0.3 \mathrm{~g})$ dissolved in $2 \mathrm{M}$ urea $(15 \mathrm{ml})$ was applied to a column $(3 \times 10 \mathrm{~cm})$ of DEAE-Sephadex A-25 $\left(\mathrm{HCO}_{3}{ }^{-}\right)$. The column was eluted successively with $2 \mathrm{M}$ urea $(120 \mathrm{ml}), 0.45 \mathrm{M}$ ammonium bicarbonate containing $2 \mathrm{M}$ urea $(120 \mathrm{ml})$, and $2 \mathrm{M}$ sodium chloride containing $2 \mathrm{M}$ urea $(120 \mathrm{ml})$. Each eluate was dialyzed against tap water for $2 \mathrm{~d}$ and distilled water for $1 \mathrm{~d}$. The non-dialyzable fraction was concentrated and lyophilized. The fractions were named neutral fraction $(-\mathrm{N})$, acidic fraction $(-\mathrm{A})$, and strongly acidic fraction $(-\mathrm{Cl})$.

Quantitative Analysis - - Total sugar contents were determined as anhydroglucose by the phenol-sulfuric acid method. ${ }^{5)}$ Total protein contents were determined as bovine serum albumin by the Lowry-Folin method. ${ }^{6)}$ Total phosphate contents were determined by the method of Chen et al. ${ }^{7)}$ Total uronic acid contents were determined as galacturonic acid by the carbazole-sulfuric acid method. ${ }^{83}$

Susceptibility to $\boldsymbol{\alpha}$-Amylase - - Each fraction $(9 \mathrm{mg}$ ) was dissolved in $10 \mathrm{~mm}$ tris- $\mathbf{H C l}$ buffer $\mathrm{pH} 6.9(20 \mathrm{ml})$ and digested with $\alpha$-amylase (Wako Pure Chemical Ltd.) $(1 \mathrm{mg})$ at $37^{\circ} \mathrm{C}$ for $6 \mathrm{~h}$. The reaction was terminated by heating at $100^{\circ} \mathrm{C}$ for $3 \mathrm{~min}$, and dialyzed against water. The non-dialyzable fraction was concentrated.

Methylation Analysis of Each Polysaccharide Fraction — Each polysaccharide fraction was methylated by the method of Hakomori. The fully O-methylated product was formolyzed with $90 \% \mathrm{HCOOH}(1 \mathrm{ml})$ at $100^{\circ} \mathrm{C}$ for $10 \mathrm{~h}$ in a sealed tube. After removal of the $\mathrm{HCOOH}$ by evaporation the residue was hydrolyzed with $1 \mathrm{~m}$ trifluoroacetic acid at $100^{\circ} \mathrm{C}$ for $5 \mathrm{~h}$, then the mixture was evaporated to dryness. The resulting partially $\mathrm{O}$-methylated sugars were reduced with $\mathrm{NaBH}_{4}$ for $2 \mathrm{~h}$ to the corresponding alditols, and then acetylated with a mixture of pyridine and acetic anhydride at $100^{\circ} \mathrm{C}$ for $1 \mathrm{~h}$. Gas liquid chromatography (GLC) of the partially O-methylated alditol acetates was carried out on a glass column $(0.3 \times 200 \mathrm{~cm})$ packed with $0.3 \% \mathrm{OV}-275 / 0.4 \% \mathrm{XF}-1150$ at increasing temperature $\left(2{ }^{\circ} \mathrm{C} / \mathrm{min}\right)$ from 120 to $190^{\circ} \mathrm{C}$. The molar ratio of $\mathrm{O}$-methylated sugars was calculated based on 1,5 -di- $O$-acetyl2,3,4,6-tetra- $O$-methyl-D-glucitol as 1.0 .

Carbon-13 Nuclear Magnetic Resonance $\left({ }^{13} \mathrm{C}-\mathrm{NMR}\right)$ Spectral Analysis- -13 C-NMR spectra were recorded at $60^{\circ} \mathrm{C}$ for solutions in DMSO- $d_{6}$ with a JEOL FX-200 spectrometer at $50.1 \mathrm{MHz}$. The spectra were obtained in the pulsed Fourier-transform mode with complete proton decoupling.

\section{Results}

As shown in Fig. 1, the water-soluble polysaccharide fraction extracted from the cultured fruit bodies of $G$. frondosa with hot sodium hydroxide (CF-7) was separated into neutral (CF$7 \mathrm{~N})$, acidic $(0.45 \mathrm{M}$ ammonium bicarbonate, $\mathrm{CF}-7 \mathrm{~A})$, and strongly acidic ( $2 \mathrm{M}$ sodium hydroxide, $\mathrm{CF}-7 \mathrm{Cl})$ fraction on a DEAE-Sephadex A-25 $\left(\mathrm{HCO}_{3}{ }^{-}\right)$column. CF-1 and CF-5 showed similar elution profiles from the DEAE-Sephadex A-25 $\left(\mathrm{HCO}_{3}{ }^{-}\right)$column. For largescale preparation, stepwise elution as shown in Fig. 2 was performed. The yield of each fraction was similar from each extract. About half of each extract was recovered from the neutral fraction. The acidic and strongly acidic fractions corresponded to about 20 and $10 \%$ of the starting materials, respectively. The neutral and acidic fractions of each extract were composed of a large amount of carbohydrates, but the strongly acidic fractions contained a 


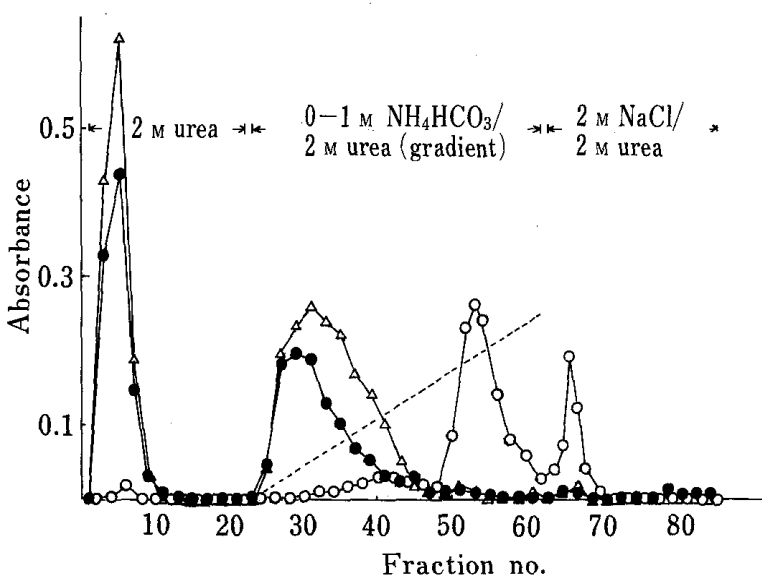

Fig. 1. Elution Profiles of Polysaccharide Fraction CF-7 from a Column of DEAE-Sephadex A-25 $\left(\mathrm{HCO}_{3}{ }^{-}\right)$

The column $(1.5 \times 6 \mathrm{~cm})$ was equilibrated with $2 \mathrm{M}$ urea, and $20 \mathrm{mg}$ of $\mathrm{CF}-7$ was applied. Fractions of $2.4 \mathrm{ml}$ were collected and carbohydrate (- - - ), protein $(-\mathrm{O}--)$, and ùronic acid $(-\Delta-)$ were assayed by the phenol-sulfuric acid method, by ultraviolet absorption measurement, and by the carbazole-sulfuric acid method, respectively.

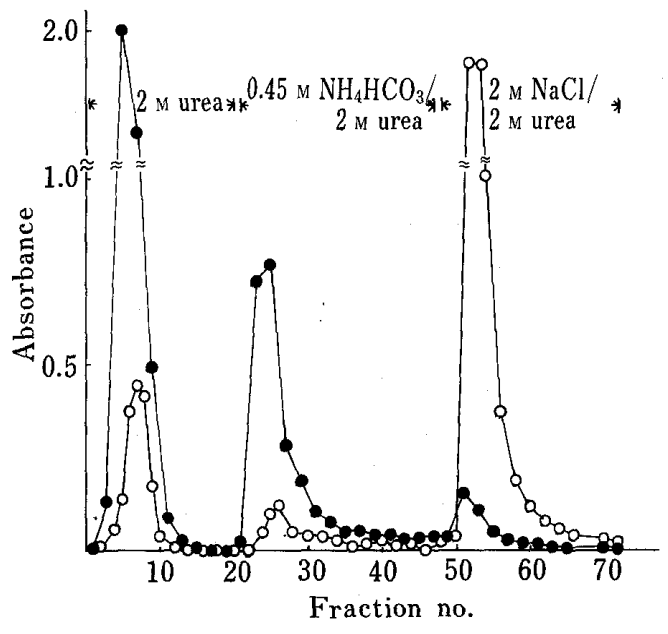

Fig. 2. Elution Profiles of Polysaccharide Fraction $\mathrm{CF}-7$ from a Column of DEAE-Sephadex A-25 $\left(\mathrm{HCO}_{3}{ }^{-}\right)$

The column $(1.5 \times 6 \mathrm{~cm})$ was equilibrated with $2 \mathrm{M}$ urea, and $35 \mathrm{mg}$ of CF-7 was applied. Fractions of $2.4 \mathrm{ml}$ were collected and carbohydrate (- --$)$ and protein (-O-) were assayed by the phenol-sulfuric acid method, and by ultraviolet absorption measurement, respectively.

TABLE I. Some Properties of Polysaccharide Fractions of Grifola frondosa Isolated on a DEAE-Sephadex A-25 $\left(\mathrm{HCO}_{3}{ }^{-}\right)$Column

\begin{tabular}{|c|c|c|c|c|c|c|}
\hline Fraction & $\begin{array}{l}\text { Yield } \\
(\%)\end{array}$ & $\begin{array}{c}\text { Sugar } \\
(\%)\end{array}$ & $\begin{array}{c}\text { Protein } \\
(\%)\end{array}$ & $\begin{array}{c}\text { Phosphate } \\
(\%)\end{array}$ & $\begin{array}{c}\text { Uronic } \\
\text { acid }(\%)^{a)}\end{array}$ & $\begin{array}{c}\alpha \text {-Amylase } \\
\left.\text { digestion }(\%)^{b}\right)\end{array}$ \\
\hline $\mathrm{CF}-1 \mathrm{~N}$ & 30.5 & 91.5 & 1.1 & 0.1 & 0 & 23.3 \\
\hline CF-1A & 23.1 & 39.5 & 45.7 & 0.9 & 0 & 66.1 \\
\hline $\mathrm{CF}-1 \mathrm{Cl}$ & 8.3 & 22.5 & 20.2 & 12.5 & 1.1 & n.d. ${ }^{c)}$ \\
\hline $\mathrm{CF}-5 \mathrm{~N}$ & 49.5 & 78.2 & 5.3 & 0.2 & 0 & 58.1 \\
\hline CF $-5 A$ & 16.1 & 44.6 & 39.4 & 0.2 & 4.6 & 100 \\
\hline $\mathrm{CF}-5 \mathrm{Cl}$ & 10.4 & 11.4 & 70.2 & 0.2 & 2.0 & n.d. \\
\hline CF-7N & 55.1 & 83.0 & 3.6 & 0.2 & 0 & 61.3 \\
\hline $\mathrm{CF}-7 \mathrm{~A}$ & 20.2 & 75.6 & 4.5 & 0.04 & 2.3 & 99.7 \\
\hline CF7C 1 & 7.6 & 24.2 & 59.5 & 0.02 & 1.7 & n.d. \\
\hline
\end{tabular}

a) Each value was obtained after correction for interference by neutral sugar. b) Remained after dialysis as non-dialyzable fractions. c) Not determined.

large amount of protein. The strongly acidic fraction could not be analyzed because the sugar content was too low. Further, the acidic fractions contain uronic acid and/or protein.

The antitumor effect of each fraction was assayed by comparing the growth of Sarcoma 180 tumor cells in ICR mice. The results are shown in Table III. It was found that all fractions showed inhibition of the tumor growth.

The linkages of each fraction were analyzed by methylation, ${ }^{13} \mathrm{C}-\mathrm{NMR}$ spectroscopy, and $\alpha$-amylase digestion, and the results are shown in Tables I and II, and Fig. 3. The most abundant linkage in $\mathrm{CF}-1 \mathrm{~N}$ was found to be $\alpha-1,4$ as deduced from the results of $\alpha$-amylase digestion (Table I). CF-1 N also contained a small but significant amount of 6-branched $\beta-1,3$ glucan (Table II). CF-5N and -7N contained larger amounts of 6 -branched $\beta-1,3$ glucan than $\mathrm{CF}-1 \mathrm{~N}$. The content of 6-branched $\beta-1,3$ glucan was the greatest in CF-7N. 
TABLE II. Gas Liquid Chromatography of Alditol Acetates Derived from the Methylated Polysaccharides

\begin{tabular}{|c|c|c|c|c|c|c|}
\hline Alditol acetate of & $C F-1 N$ & $\mathrm{CF}-1 \mathrm{~A}$ & CF-5N & CF-5A & $\mathrm{CF}-7 \mathrm{~N}$ & $\mathrm{CF}-7 \mathrm{~A}$ \\
\hline $2,3,4,6-\mathrm{Me}_{4}-\mathrm{Glc}$ & 1.0 & 1.0 & 1.0 & 1.0 & 1.0 & 1.0 \\
\hline $2,4,6-\mathrm{Me}_{3}-\mathrm{Glc}$ & 0.11 & 0.31 & 0.69 & 0.90 & 1.02 & 1.35 \\
\hline $2,3,4-\mathrm{Me}_{3}-\mathrm{Glc}$ & 0.0 & 0.78 & 0.04 & 0.92 & 0.11 & 1.22 \\
\hline 2,3,6-Me $-\mathrm{Glc}$ & 8.01 & 2.14 & 4.27 & 0.04 & 3.94 & 0.07 \\
\hline $2,6-\mathrm{Me}_{2}-\mathrm{Glc}$ & 0.05 & 0.38 & 0.09 & 0.22 & 0.05 & 0.08 \\
\hline $3,4,6-\mathrm{Me}_{3}-\mathrm{Glc}$ & 0.0 & 0.0 & 0.0 & 0.0 & 0.0 & 0.01 \\
\hline $2,4-\mathrm{Me}_{2}-\mathrm{Glc}$ & 0.0 & 0.33 & 0.40 & 0.76 & 0.51 & 0.97 \\
\hline 2,3-Me $-\mathrm{Me}_{2}-\mathrm{Glc}$ & 0.85 & 0.27 & 0.45 & 0.01 & 0.43 & 0.0 \\
\hline 3,6- $\mathrm{Me}_{2}-\mathrm{Glc}$ & 0.10 & 0.36 & 0.1 .1 & 0.15 & 0.08 & 0.07 \\
\hline
\end{tabular}

TABLE III. Antitumor Effect of Polysaccharide Fractions from Grifola frondosa ${ }^{a}$

\begin{tabular}{|c|c|c|c|c|c|c|}
\hline Sample & $\begin{array}{c}\text { Dose } \\
(\mu \mathrm{g} \times 10)\end{array}$ & $\begin{array}{l}\text { No. of } \\
\text { mice }\end{array}$ & $\begin{array}{l}\text { Tumor weight } \\
\text { (g, mean } \pm \text { S.D.) }\end{array}$ & $\begin{array}{l}\text { Inhibition } \\
\text { ratio }(\% /)^{b)}\end{array}$ & $\begin{array}{l}\text { C.R. } \\
(\%)^{b)}\end{array}$ & $\begin{array}{c}\text { Significance } \\
p^{c)}<\end{array}$ \\
\hline \multirow[t]{3}{*}{ CF-1N } & 100 & 6 & $8.4 \pm 4.7$ & -7.8 & 0 & n.s. ${ }^{d)}$ \\
\hline & 400 & 6 & $6.7 \pm 3.2$ & 15 & 0 & n.s. ${ }^{d)}$ \\
\hline & 1600 & 6 & $2.6 \pm 2.8$ & 67 & 33 & 0.01 \\
\hline \multirow[t]{3}{*}{ CF-1A } & 100 & 7 & $7.3 \pm 3.0$ & 6.8 & 0 & n.s. ${ }^{d)}$ \\
\hline & 400 & 7 & $3.8 \pm 3.5$ & 51 & 14 & 0.05 \\
\hline & 1600 & 7 & $7.1 \pm 5.5$ & 9.2 & 14 & n.s..$^{d)}$ \\
\hline $\mathrm{CF}-1 \mathrm{C} 1$ & 400 & 7 & $8.1 \pm 2.9$ & -3.6 & 0 & n.s..$^{d\}}$ \\
\hline \multirow[t]{5}{*}{ CF-5N } & 6.25 & 6 & $6.0 \pm 2.9$ & 22 & 0 & n.s. ${ }^{d)}$ \\
\hline & 25 & 7 & $2.7 \pm 2.6$ & 65 & 29 & 0.01 \\
\hline & 100 & 7 & $0.8 \pm 1.9$ & 90 & 14 & 0.001 \\
\hline & 400 & 7 & $1.8 \pm 2.2$ & 76 & 0 & 0.001 \\
\hline & 1600 & 7 & $1.3 \pm 0.9$ & 83 & 0 & 0.001 \\
\hline \multirow[t]{5}{*}{ CF-5A } & 6.25 & 7 & $6.6 \pm 3.7$ & 16 & 0 & n.s. ${ }^{d)}$ \\
\hline & 25 & 7 & $3.1 \pm 2.5$ & 60 & 0 & 0.01 \\
\hline & 100 & 7 & $1.6 \pm 1.5$ & 79 & 0 & 0.001 \\
\hline & 400 & 7 & $1.1 \pm 1.2$ & 86 & 14 & 0.001 \\
\hline & 1600 & 7 & $2.2 \pm 2.5$ & 71 & 0 & 0.001 \\
\hline \multirow[t]{2}{*}{$\mathrm{CF}-5 \mathrm{Cl}$} & 100 & 6 & $8.2 \pm 3.3$ & -4.5 & 0 & n.s. ${ }^{d)}$ \\
\hline & 400 & 6 & $1.5 \pm 2.3$ & 81 & 17 & 0.001 \\
\hline \multirow[t]{5}{*}{$\mathrm{CF}-\mathrm{TN}$} & 1.56 & 7 & $5.2 \pm 3.1$ & 33 & 0 & n.s. ${ }^{d)}$ \\
\hline & 6.25 & 7 & $3.0 \pm 2.1$ & 62 & 0 & 0.01 \\
\hline & 25 & 7 & $1.7 \pm 1.9$ & 78 & 0 & 0.001 \\
\hline & 100 & 5 & $0.3 \pm 0.3$ & 97 & 40 & 0.001 \\
\hline & 400 & 7 & $2.6 \pm 1.4$ & 66 & 0 & 0.001 \\
\hline \multirow[t]{5}{*}{ CF-7A } & 1.56 & 7 & $5.0 \pm 2.7$ & 36 & 0 & n.s. ${ }^{d)}$ \\
\hline & 6.25 & 5 & $4.5 \pm 3.1$ & 42 & 0 & n.s. ${ }^{d)}$ \\
\hline & 25 & 7 & $3.6 \pm 3.6$ & 54 & 29 & 0.02 \\
\hline & 100 & 7 & $0.8 \pm 0.7$ & 90 & 14 & 0.001 \\
\hline & 400 & 6 & $0.9 \pm 1.0$ & 88 & 17 & 0.001 \\
\hline \multirow[t]{2}{*}{$\mathrm{CF} 7 \mathrm{Cl}$} & 100 & 6 & $2.7 \pm 2.4$ & 66 & 33 & 0.01 \\
\hline & 400 & 6 & $0.9 \pm 1.4$ & 89 & 17 & 0.001 \\
\hline Control & - & 12 & $7.8 \pm 3.2$ & - & 0 & - \\
\hline
\end{tabular}

a) Sarcoma 180 tumor cells $\left(5 \times 10^{6}\right)$ were inoculated subcutaneously. Each sample was administered in saline by intraperitoneal injection. b) Inhibition ratio and C.R. (complete regression) were determined at $35 \mathrm{~d}$ after tumor inoculation. c) The significance was evaluated according to Student's $t$-test, and $p<0.05$ was taken as the criterion of a significant difference. $d$ ) Not significant. 

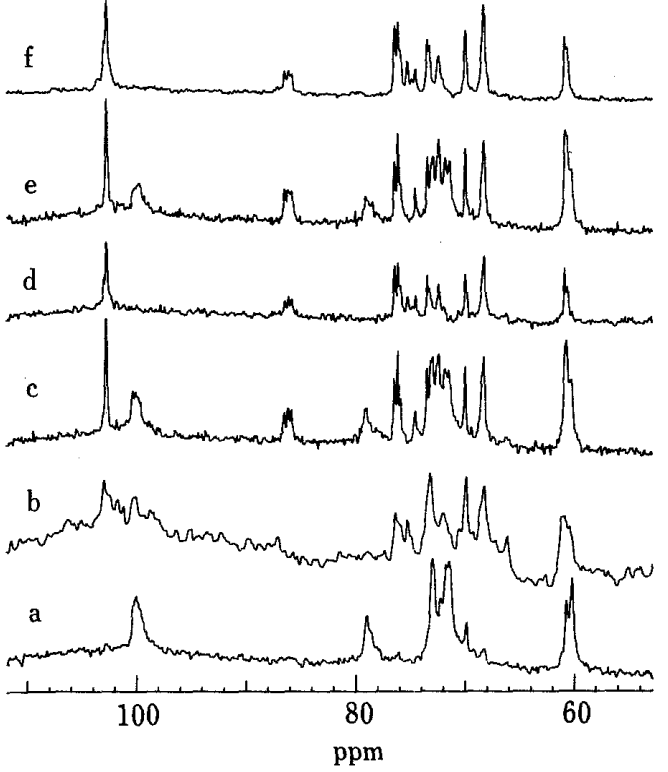

Fig. 3. ${ }^{13} \mathrm{C}-\mathrm{NMR}$ Spectra of Polysaccharide Fractions in DMSO- $d_{6}$

a, CF-1N; b, CF-1A; c, CF-5N; d, CF-5A; e, CF$7 \mathrm{~N} ; \mathrm{f}, \mathrm{CF}-7 \mathrm{~A}$. Values are given in ppm (DMSO as $39.5 \mathrm{ppm})$.

The ${ }^{13} \mathrm{C}-\mathrm{NMR}$ spectra of neutral fractions were consistent with the results of enzymic and methylation analysis; signals at $100 \mathrm{ppm}$ and $80 \mathrm{ppm}$ (Fig. 3) were attributable to C-1 and C-4 of $\alpha-1,4$ glucan, respectively. Signals of $\beta-1,3$ glucan appeared clearly in the spectra of CF$5 \mathrm{~N}$ and $-7 \mathrm{~N}$. These signals were not clearly observed in the spectrum of $\mathrm{CF}-1 \mathrm{~N}$ because of the small content. The triplet signal at $86 \mathrm{ppm}$ is a characteristic signal of branched $\beta-1,3$ glucans, such as lentinan and scleroglucan. It appears that the $\beta-1,3$ glucan obtained from $G$. frondosa is similar to the above polysaccharides.

CF-1A contained $\alpha-1,4, \beta-1,6$, and 6-branched $\beta-1,3$ linkages, while CF-5A and -7A contained $\beta-1,6$ and 6-branched $\beta-1,3$ linkages. All these fractions appear to share the basic 6branched $\beta-1,3$ glucan structure of the neutral fractions, because the ${ }^{13} \mathrm{C}$-NMR spectra in DMSO $-d_{6}$ of these fractions showed similar triplet signals $(86 \mathrm{ppm})$ attributable to C-3 of the $\beta$-glucosyl unit.9) Thus the antitumor activity of $G$. frondosa is considered to be due to branched $\beta-1,3$ glucan. The acidic fractions are presumably substituted with some anionic residues, possibly uronic acid (Table I).

In the previous paper, we reported that the optimum doses of CF-1, -5 , and -7 were 4000 , 400 , and $40-400 \mu \mathrm{g} / \mathrm{d} \times 10$, respectively. These doses were correlated with the content of $\beta-1,3$ glucan in these fractions. In the present paper, the optimum doses of $C F-5 N,-5 A,-7 N$, and $-7 A$ were found to be about $100 \mu \mathrm{g} / \mathrm{d} \times 10$, while that of CF-1N was more than $1600 \mu \mathrm{g} / \mathrm{d} \times 10$. These optimum doses are also correlated with the $\beta-1,3$ glucan contents.

\section{Discussion}

As described in Results, the water-soluble polysaccharide fractions extracted from the cultured fruit bodies of Grifola frondosa were separated into neutral and acidic glucans. Recently, we reported that the antitumor activity of water-soluble polysaccharide fractions from Grifola frondosa was not lowered by $\alpha$-amylase digestion or periodate oxidation. The data presented in this paper suggest that the activity of both neutral and acidic glucans is due to 6-branched $\beta-1,3$ glucan, and the glucan is considered to be branched at every three 3substituted $\beta$-glucosyl units. The primary structure of this $\beta$-glucan is very similar to those of lentinan ${ }^{10)}$ and scleroglucan..$^{9,11)}$

Many antitumor glucans derived from Basidiomycetes (e.g. lentinan ${ }^{10)}$ and schizophil$\operatorname{lan}^{12)}$ ) are known to be neutral, though PS-K is a protein-bound antitumor polysaccharide 
having acidic groups. ${ }^{2)}$ The protein content of PS-K is about $15 \%$, and the major component sugars are glucose $(74.6 \%)$, mannose $(15.5 \%)$, galactose $(2.7 \%)$, xylose $(4.8 \%)$, and fucose $(2.4 \%)$. The acidity of PS-K is thought to be due to the presence of amino acid residues, such as aspartic acid and glutamic acid. Recently, Hashimoto et al. reported that a yeast mannan fraction called WAM-025 contained mannose $(93.6 \%)$, nitrogen $(1.0 \%)$, and phosphate $(0.6 \%),{ }^{13)}$ the acidity of WAM- 025 might be due to the presence of phosphate groups. Both PS-K and WAM-025 showed potent antitumor activity towards allogeneic and syngeneic systems in mice by activating the peritoneal adherent cells. On the other hand as shown in Table I, the acidic groups in the acidic fraction of Grifola frondosa may be uronic acid residues.

Recently, we reported an antitumor polysaccharide fraction, GF-1, from the hot water extract of $G$. frondosa, and found that GF-1 showed a different mode of antitumor action from both lipopolysaccharide and lentinan. ${ }^{4}$ The data obtained in the present paper suggest that the acidic glucan plays an important role in the characteristic properties of GF-1. Further investigations of these antitumor glucans are in progress.

Acknowledgments The authors thank Miss T. Itani and Mr. T. Kinoshita for their technical assistance.

\section{References}

1) G. Chihara, Y. Y. Maeda, J. Hamuro, T. Sasaki, and F. Fukuoka, Nature (London), 222, 687 (1969).

2) S. Tsukagoshi and F. Ohashi, Gann, 65, 557 (1974).

$3)$ N. Ohno, I. Suzuki, S. Oikawa, K. Sato, T. Miyazaki, and T. Yadomae, Chem. Pharm. Bull., 32,1142 (1984).

4) I. Suzuki, T. Itani, N. Ohno, S. Oikawa, K. Sato, T. Miyazaki, and T. Yadomae, J. Pharmacobio-Dyn., 7, 492 (1984).

5) M. Dubois, K. Gilles, J. K. Hamilton, P. A. Robers, and F. Smith, Anal. Chem., 28, 350 (1956).

6) H. O. Lowry, N. J. Rosebrough, A. L. Farr, and R. L. Randall, J. Biol. Chem., 193, 256 (1951).

7) Jr. P. S. Chen, T. Toribara, and H. Warner, Anal. Chem., 28, 1756 (1956).

8) J. T. Galambos, Anal. Biochem., 19, 119 (1967).

9) M. Rinaudo and M. Vincendon, Carbohydr. Polymer, 2, 135 (1982).

10) G. Chihara, J. Hamuro, Y. Y. Maeda, Y. Arai, and F. Fukuoka, Cancer. Res., 30, 2776 (1970).

11) P. P. Singh, R. L. Whistler, R. Tokuzen, and W. Nakahara, Carbohydr. Res., 37, 245 (1974).

12) N. Komatsu, S. Okubo, S. Kikumoto, K. Kimura, G. Sato, and S. Sasaki, Gann, 60, 137 (1969).

13) K. Hashimoto, Y. Okawa, K. Suzuki, Y. Okura, S. Suzuki, and M. Suzuki, J. Pharmacobio-Dyn., 6, 668 (1983). 